\title{
Praktyki postne w wybranych relacjach pisarzy kościelnych greckich i lacińskich I-III wieku
}

Niniejszy artykuł stanowi studium tekstów pisarzy kościelnych I-III wieku dokonane w celu opisu omawianych w nich praktyk postnych przy zastosowaniu metod właściwych naukom patrystycznym. Przedstawię krytycznie treść kolejnych dzieł wybranych autorów greckich i łacińskich w ujęciu chronologicznym. Określenie „wybranych” oznacza tu pisarzy uznanych za najbardziej reprezentatywnych dla podejmowanej tematyki w swoim czasie. W I-II wieku zagadnienie postu religijnego podjęli szerzej trzej następujący autorzy spośród pisarzy apostolskich: anonimowy autor Didache, anonimowy autor Listu Pseudo-Barnaby oraz Hermas. Natomiast dla II-III wieku reprezentatywnymi dla tematyki postu byli wśród pisarzy greckich Klemens Aleksandryjski i Orygenes, a dla pisarzy łacińskich - kompilator tekstu tzw. Tradycji apostolskiej (Josipos bądź Hipolit) i Tertulian (wtedy już montanista).

\section{Pisarze apostolscy o praktyce postu}

Pierwszymi pozabiblijnymi tekstami chrześcijańskimi, w których odnajdujemy tematykę postu podejmowanego z powodów religijnych, są trzy utwory z okresu ojców apostolskich, tj. Didache, List Pseudo-Barnaby oraz Pasterz Hermasa. Problematyka ta jest w owych utworach przedstawiana najczęściej w formie duszpasterskiej ekshortacji, rady czy dydaktycznej zachęty. Wezwania tego typu były uwarunkowane doraźną potrzebą mo-

1 Prof. dr hab. Dariusz Kasprzak OFMCap, profesor uczelni, pracownik Katedry Patrologii w Instytucie Teologii Dogmatycznej na Wydziale Teologicznym Uniwersytetu Papieskiego Jana Pawła II w Krakowie; e-mail: dariusz.kasprzak@upjp2.edu.pl; ORCID: 0000-0003-0137-3514. 
ralną bądź ascetyczną wspólnoty chrześcijańskiej. Nie były to teoretyczne rozważania filozoficzne, ale duszpasterskie zachęty o motywacji ewangelicznej. W rozważanych tekstach autorów poapostolskich znajdujemy wyraźne odniesienia do postów żydowskich.

Zalecenie „pośćcie za waszych prześladowców”2 stanowi zdaniem autora Didache (zredagowane ok. drugiej połowy I wieku) część „drogi życia”, wynika z Chrystusowego prawa miłości (por. Didache I 2, por. Mt 22,37-40) ${ }^{3}$. Bezpośrednią przesłanką biblijną wspomnianego zalecenia postu podejmowanego w intencji prześladowców jest tekst Mt 5,444. Post za prześladowców/nieprzyjaciół jest postem typowo chrześcijańskim, bo poganie tego nie czynią. Wynika on z chrześcijańskiej postawy miłości i zmierza w swym skutku do tego, aby nie mieć nieprzyjaciół $1^{5}$. Chrześcijański post łączy się też ściśle z postawą jałmużny wobec potrzebujących (por. Didache I 4-6). Wspomniane trzy postawy (modlitwa, post, jałmużna), wypływając z błogosławieństw ewangelicznych, stanowią istotę chrześcijańskiego praktykowania wiary ${ }^{6}$.

W kontekście chrześcijańskiej liturgii chrzcielnej pojawia się w dalszej części Didache kolejne wskazanie dotyczące praktykowania postu. Był nim obowiązek poszczenia przed chrztem zarówno przez przyjmującego chrzest, jak i tego, który go udzielał, innym członkom Kościoła natomiast post był zalecany, ale nie stanowił dla nich obowiązku. Dodatkowo anonimowy autor tekstu precyzuje, by kandydat do chrztu pościł dzień lub dwa przed jego przyjęciem ${ }^{7}$. Poszczenie połączone z modlitwą i jałmużną wtajemniczanego pośrednio wynikało z tradycji żydowskiej (por. Jon 3,7; 2Sam 12,16; Iz 58,6-7). Dla chrze-

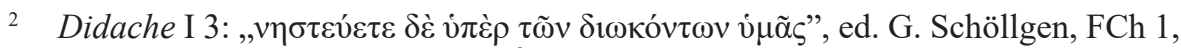
Freiburg im Breisgau 1991, s. 100, tł. A. Świderkówna, BOK 10, Kraków 1998, s. 33.

3 Mt 22,37-40: „Będziesz miłował Pana Boga swego całym swoim sercem, całą swoją duszą i całym swoim umysłem. To jest największe i pierwsze przykazanie. Drugie podobne jest do niego: Będziesz miłował swego bliźniego jak siebie samego. Na tych dwóch przykazaniach opiera się całe Prawo i Prorocy" (Biblia Tysiąclecia).

4 Mt 5,44: „A Ja wam powiadam: Miłujcie waszych nieprzyjaciół i módlcie się za tych, którzy was prześladują" (Biblia Tysiąclecia).

5 Por. Didache I 3b, FCh 1, s. 100, tł. A. Świderkówna, BOK 10, s. 33: „Jakaż to zasługa, jeśli miłujecie tych, którzy was miłują? Czyż i poganie tego nie czynią? Wy natomiast miłujcie tych, którzy was nienawidzą, a nie będziecie mieć nieprzyjaciół". Zob. Mt 5,46; Łk 6,32.

6 Por. J.-P. Audet, La Didaché: instructions des Apôtres, Paris 1958, s. 265.

7 Por. Didache VII 4, FCh 1, s. 118, tł. A. Świderkówna, BOK 10, s. 36: „Przed chrztem powinni pościć i chrzczony, i udzielający chrztu, a także inni, jeśli mogą. Temu zaś, kto ma być chrzczony, przykaż, by pościł przez dzień lub dwa dni przedtem”. 
ścijan praktyka postu ma swe bezpośrednie źródło w przykładzie życia Jezusa (por. Mt 4,1-11) ${ }^{8}$.

Ostatnią wskazówką autora Didache dotyczącą praktykowania postu, wypowiedzianą w kontekście chrześcijańskiej modlitwy Pańskiej, było zachowywanie przez chrześcijan postu w dni odmienne od postu żydowskiej sekty faryzeuszy nazwanych w tym tekście obłudnikami. Taki chrześcijański post miał się odbywać w środę i w piątek, a nie w poniedziałek i czwartek ${ }^{9}$. Nazwanie faryzeuszy „obłudnikami”, w nawiązaniu do ich praktyk postnych, niewątpliwie pochodzi z Mt $6,16^{10}$. Tora zobowiązywała Żydów tylko do jednego dnia postu w roku, w Dniu Przebłagania (por. $\mathrm{Kpł} 16,29-31$ ). Z czasem jako drugi zasadniczy post dodano w tradycji żydowskiej Tisza be-Aw (por. Talmud babiloński Taanit 26,2) ${ }^{11}$. Tylko te dwa posty rozumiano jako ścisłe (bez jedzenia, picia, wykonywania jakiejkolwiek pracy, trwające od zachodu jednego dnia do zachodu dnia następnego). Pozostałe pięć postów żydowskich (Sziwa Asar be-Tam(m)uz, Asara be-Tewet, Post Gedaliasza, Post Estery, Post Pierworodnych) zostały wprowadzone później przez rabinów ${ }^{12}$ jako upamiętnienie żydowskich

8 Por. E. Ferguson, Baptism in the Early Church. History, Theology, and Liturgy in the First Five Centuries, Grand Rapids 2009, s. 201-206.

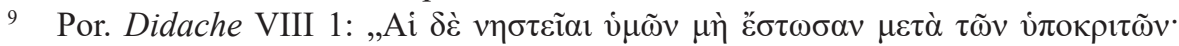

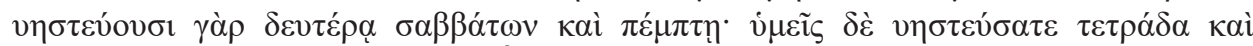

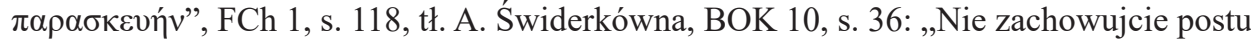
w tym samym czasie, co obłudnicy. Oni bowiem poszczą w poniedziałek i czwartek, wy natomiast pośćcie w środę i piątek”.

10 Mt 6,16: „Kiedy pościcie, nie bądźcie posępni jak obłudnicy. Przybierają oni wygląd ponury, aby pokazać ludziom, że poszczą. Zaprawdę, powiadam wam: już odebrali swoją nagrodę" (Biblia Tysiąclecia). Kiedy ewangelista wskazuje na odmienny sposób poszczenia (Mt 6,17-18: „Ty zaś, gdy pościsz, namaść sobie głowę i umyj twarz, aby nie ludziom pokazać, że pościsz, ale Ojcu twemu, który jest w ukryciu. A Ojciec twój, który widzi w ukryciu, odda tobie), autor Didache zwraca uwagę na odmienność dni postnych pomiędzy chrześcijanami a Żydami.

11 Talmud jako katechetyczny komentarz do Pięcioksięgu zawiera w sobie żydowską tradycję ukształtowaną między III wiekiem przed Chrystusem a VI wiekiem po Chrystusie, dlatego zarówno w starożytności, jak i współcześnie stanowi główne odniesienie, do którego odwołują się rabini przy rozstrzyganiu sporów. Z metodologicznego punktu widzenia wydaje się zatem jak najbardziej uzasadnione odniesienie do zawartych w nim tradycji żydowskich dotyczących formowania się praktyk postnych. Zob. N. KamerazKos, Święta i obyczaje żydowskie, Warszawa 2002, s. 18; K. Pilarczyk, Literatura żydowska od epoki biblijnej do haskali. Wprowadzenie religioznawcze, literackie i historyczne, Kraków 2006, s. 219.

12 Por. Classification of Fasts, w: Encyclopaedia Judaica, t. 6, red. C. Roth, Jerusalem 1973, s. 1195-1196. 
klęsk narodowych i nadano im znaczenie powszechnych. Nie miały one znaczenia postu ścisłego, jak dwa pierwsze posty, dlatego w te dni postne należało się powstrzymać od jedzenia i picia tylko od wschodu do zachodu słońca. W tradycji żydowskiej bywały też posty prywatne, które rozpowszechniły się dopiero po zburzeniu przez Rzymian drugiej świątyni w Jerozolimie w 70 roku. W czasach Jezusa prywatne posty żydowskie nie były więc powszechne, miały charakter czasowy, do wyjątków należało stałe poszczenie ${ }^{13}$. Krytyka ewangelii synoptycznych (Mk 2,18; Mt 6,2-18; Łk 5,33) wobec prywatnych postów faryzeuszy dotyczy tego, że faryzeusze nie dostrzegają obecności Mesjasza i zamiast się nią radować, poszczą. Wynika z tego, że Prawo Mojżeszowe i tradycja rabinacka zobowiązywały Żydów przed 70 rokiem jedynie do kilku postów w ciągu roku, faryzeusze natomiast dodatkowo mogli pościć także dwa dni w tygodniu - w poniedziałki i we czwartki (por. Didache 8,1; Talmud jerozolimski Pesahim 4,1; Talmud babiloński Taanit 12 a). Także po 70 roku poszczenie dwa razy w tygodniu nie było faryzejską praktyką stałą, lecz okresową. Didache nawiązuje zatem do postów w judaizmie faryzejskim, które były prywatne i miały charakter okresowy. Faryzejskie poszczenie dwa razy w tygodniu (por. Łk 18,12) było raczej pojedynczym przypadkiem niezwykłej gorliwości, a nie faryzejską czy tym bardziej ogólno żydowską normą poszczenia w I wieku' ${ }^{14}$.

Annie Jaubert, próbując ustalić zasadę ustanowienia środy i piątku dniami postnymi w Didache, zauważyła, że właśnie te dwa dni miały szczególne znaczenie w kalendarzu kapłańskim stosowanym w Qumran. Był on odmienny od kalendarza faryzeuszy. Kalendarz esseńczyków był przestrzegany przez pierwotną wspólnotę chrześcijańską w Jerozolimie. Dlatego wybór środy i piątku jako dni postnych w chrześcijaństwie był prawdopodobnie pochodzenia esseńskiego. Pierwsi chrześcijanie jerozolimscy wywodzący się częściowo z ruchu esseńczyków byli podatni na przyjęcie dni postnych już celebrowanych przez esseńczyków, przenieśli natomiast na nie nowe znaczenie. W te dni chrześcijanie spotykali się na modlitwie, a samym dniom zaczęto nadawać znaczenie nowotestamentalne: środa stała się dniem postnym jako dzień, w którym Judasz zdradził Jezusa, a piątek - dniem postnym jako dzień ukrzyżowania Jezusa ${ }^{15}$. Tezę A. Jaubert podzielał też

13 Por. M.D. Herr, Fasting and Fast Days, w: Encyclopaedia Judaica, t. 6, red. C. Roth, Jerusalem 1973, s. 1189-1195.

14 Por. W. Rakocy, Faryzeusze. Historia - Ewangelie, Lublin 2002, s. 140-143.

15 Por. A. Jaubert, La date de la dernière Cène, „Revue de l'histoire des religions” 146/2 (1954) s. 168-169; A. Jaubert, Le mercredi où Jésus fut livre, „New Testament Studies" 14 (1967) s. 145-164. 
Jean Daniélou ${ }^{16}$. Wydaje się ona najlepiej tłumaczyć odmienność dni postnych $\mathrm{w}$ judaizmie typu faryzejskiego $\mathrm{i} w$ chrześcijaństwie I wieku. Z czasem w chrześcijaństwie ową odrębność chrześcijańskich i żydowskich dni postnych zaczęto wyjaśniać przy pomocy kolejnych alegorii biblijnych $^{17}$. Autor Didache zalecał praktykować post chrześcijański w dni odmienne od postów faryzeuszy, co może świadczyć zarówno o kształtowaniu się własnej świadomości religijnej Kościoła, jak i o oddzielaniu się chrześcijan od praktyk synagogalnych. Niewątpliwie jednak zalecał on post już jako praktykę chrześcijańską ${ }^{18}$.

Brakuje w tekście Didache opisu praktyki postnej oraz określenia, kiedy w danym dniu post się zaczynał, a kiedy kończył. Można postawić następującą hipotezę: uznając judeochrześcijańskie pochodzenie Didache, należy domniemywać, że jego anonimowy autor miał właśnie żydowskie, a konkretnie esseńskie, wyobrażenie praktyki postnej. Czyli postem religijnym byłoby według Didache powstrzymanie się od jedzenia i picia ${ }^{19}$ przez

16 Por. J. Daniélou, Teologia judeochrześcijańska. Historia doktryn chrześcijańskich przed Soborem Nicejskim, tł. S. Basista, Kraków 2002, s. 395. O esseńskim kolorycie ewangelicznego tekstu J 13 i o prawdopodobnym używaniu przez chrześcijan w I wieku dwóch kalendarzy żydowskich (faryzeuszy i esseńczyków), zob. E. Puech, Manuskrypty znad Morza Martwego a Nowy Testament. Nowy Mojżesz, czyli o kilku praktykach Prawa, w: Qumran. Pomiędzy Starym a Nowym Testamentem, red. H. Drawnel - A. Piwowar, Analecta Biblica Lublinensia 2, Lublin 2009, s. 214-218.

17 A. Jaubert (La date de la dernière Cène, s. 169, przyp. 4) przytacza późniejszą alegoryzację „,chrystianizującą" środę i piątek, odwołując się do tekstu Le synaxaire arménien de Ter Israel [data: 29 Kalotz / 6 Janvier], PO 18, s. 195, gdzie zapisano, że Judasz Iskariota zdradził Jezusa w środę (por. Mt 26,14-25), Adam i Ewa zgrzeszyli w piątek o „dziewiątej godzinie dnia”, a Jezus umarł zbawczo za ludzi w piątek o „dziewiątej godzinie dnia”, więc dni naznaczone zdradą i męką są niejako „,bardziej” chrześcijańskie. Zdaniem A. Scarnera (Il digiugno cristiano dalle origini al IV secolo. Contributo per una rivalutazione teologica, Roma 1990, s. 81-82) powyższe rozumowanie może wynikać z następujących zestawień: kiedy Rdz 3,8 opisuje moment następujący bezpośrednio po grzechu pierwszych ludzi, podaje, że „Gdy zaś mężczyzna i jego żona usłyszeli kroki Pana Boga przechadzającego się po ogrodzie, w porze kiedy był powiew wiatru, skryli się przed Panem Bogiem wśród drzew ogrodu". Ta pora dnia, kiedy odczuwa się powiew wiatru, odpowiadałaby „dziewiątej godzinie dnia” (czyli 15:00), kiedy umierał Jezus („Od godziny szóstej mrok ogarnął całą ziemię, aż do godziny dziewiątej” - Mt 27,45).

18 Por. Audet, La Didaché, s. 170-171. Jak zauważa Stanisław Jankowski (Praktyka pokutna w Starym Testamencie, „Seminare” 24 (2007) s. 30) post stał się praktyką pokutną popularną w judaizmie poświątynnym, poświęcono mu traktat Miszny, unikano natomiast postu w piątek, aby nie zbiegał się z postem chrześcijańskim.

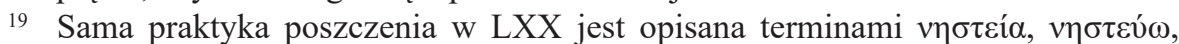

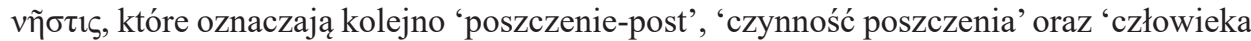


całą dobę (tj. od zachodu słońca jednego dnia do zachodu słońca dnia następnego $)^{20}$. Pojawia się natomiast pytanie, czy rzeczywiście poszczono w każdą środę i piątek tygodnia. Przyjmując ogólno żydowską wykładnię tekstu, można zaryzykować odpowiedź, że raczej nie. Taki post był zalecany dla gorliwych, ale nie był obowiązkowy, jak np. ten przed przyjęciem i udzieleniem chrztu. Przyjmując natomiast esseńską, a więc bardziej rygorystyczną i nastwioną eschatologicznie wykładnię tekstu Didache VIII 1, można uznać, że rzeczywiście poszczono dwa razy w tygodniu.

W Liście Pseudo-Barnaby (napisanym ok. 130 roku) znajdujemy jeden rozdział poświęcony postom chrześcijańskim. Tekst ten jest inspirowany Iz 58,4-10, który pseudoepigraf obszernie cytuje celem odrzucenia formalizmu w praktyce postnej. Post miły Bogu jako umartwienie ciała powinien łączyć się z postawami sprawiedliwości i miłości wobec bliźnich ${ }^{21}$. Brak tutaj szczegółowych zaleceń co do samych praktyk postnych, istotne natomiast wydaje się ideowe związanie zachowywania postu z jednoczesną praktyką sprawiedliwości i miłości przy jednoczesnym odrzuceniu rytualizmu i moralnego legalizmu.

W Pasterzu Hermasa, chrześcijańskiej apokalipsie powstałej ok. 140-150 roku w rzymskich kręgach charyzmatycznych, spotykamy fragmentaryczny opis kolejnych praktyk postnych. Autor zalecał poszczenie $\mathrm{w}$ ramach modlitwy błagalnej ${ }^{22}$ oraz post przed otrzymaniem objawienia ${ }^{23}$.

głodnego' praktykującego głodowanie jako wyraz oddania się Bogu bądź przebłagania Boga za zło czy prośby o pomyślność. Terminologia ta dzięki stosowaniu Septuaginty przez Kościół pierwszych trzech wieków stała się z czasem terminologią kościelną opisująca post. Więcej na ten temat w opracowaniu: B. Zbroja, Post w Biblii, „Polonia Sacra” 8/52 (2001) s. 441-448.

20 Por. Herr, Fasting and Fast Days, s. 1193: „Ordinary fast days lasted for the duration of the daylight hours; the important fasts were a full 24 hours"; M. Bendowska Z. Borzmińska, Posty, w: Słownik judaistyczny. Dzieje. Kultura. Religia. Ludzie, t. 2, red. Z. Borzmińska - R. Żebrowski, Warszawa 2003, s. 344-345.

21 Por. Epistula Barnabae III 1-6, ed. K. Wengst, SU 2, Darmstadt 1998, s. 142.144, tł. A. Świderkówna, BOK 10, Kraków 1998, s. 180-181.

22 Por. Hermas, Pastor 18, 6: „[...] I nocą ujrzałem w widzeniu ową sędziwą niewiastę, która mi powiedziała: «Każda prośba wymaga pokory. Zacznij więc pościć,

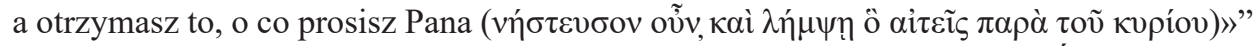
(ed. U.H. Körtner - M. Leutzsch, SU 3, Darmstadt 1998, s. 178, 180, tł. A. Świderkówna, BOK 10, s. 224).

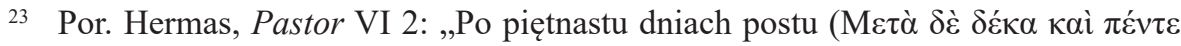

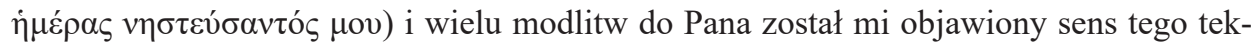
stu”. SU 3, s. 154; BOK 10, s. 214; Hermas, Pastor IX 1-2: „Oto jakie miałem widzenie, bracia. Pościłem wiele razy ( $v \eta \sigma \tau \varepsilon v ́ \sigma \alpha \varsigma \pi \mathrm{o} \lambda \lambda \alpha \dot{\alpha} \kappa \varsigma \varsigma)$ i prosiłem Pana, aby udzielił mi tego objawienia, które mi obiecał ukazać za pośrednictwem owej sędziwej niewiasty. A tejże 
Warunkiem postu pięknego i doskonałego jest zachowywanie Bożych przykazań, wystrzeganie się złych słów i pragnień oraz oczyszczenie serca ze światowych próżności ${ }^{24}$. Źródłem biblijnym dla takiej postawy postnej i wskazaniem na powiązanie skuteczności postu przed Bogiem ze sprawiedliwością i miłosierdziem poszczącego jest oczywiście tekst Iz 58,4-12. Nowością w praktyce chrześcijańskiego poszczenia natomiast był post o chlebie i wodzie (dotychczas poszczono w chrześcijaństwie tak jak w religii żydowskiej - bez jedzenia i picia). Post taki miał łączyć się z udzielaniem jałmużny, której wielkość obliczano na podstawie ilości pieniędzy, jakie należało by wydać na jedzenie $\mathrm{w}$ danym dniu, a jakie zaoszczędza się dzięki praktyce postu. Post winien też łączyć się z postawą pokory, przez co jest on miły Bogu. Hermas ponadto warunkował skuteczność modlitwy prośby zachowywaniem postu. Zachęcał też do poszczenia nie tylko indywidualnego, ale wraz z dziećmi i z całym domem ${ }^{25}$.

Przygotowanie do objawienia przez modlitwę, błaganie poprzez poszczenie, pokutę i uniżenie ma swe źródło biblijne w Dn 9,3. W żydowskiej apokaliptyce apokryficznej natomiast znajdujemy analogiczne powiązanie objawień z czasem po zakończeniu postu. W Czwartej Księdze Ezdrasza (ok. 100 rok) Ezdrasz posłuszny aniołowi Urielowi pościł i otrzymał pięć wstępnych wizji po poście siedmiodniowym i ostateczną szóstą wizję po poście trzydniowym ${ }^{26}$; w Apokalipsie Barucha syryjskiej (pierwsze dekady

samej nocy ujrzałem tę niewiastę i rzekła mi ona [...]" (SU 3, s. 160, tł. A. Świderkówna, BOK 10, s. 216; por. Dn 9,3).

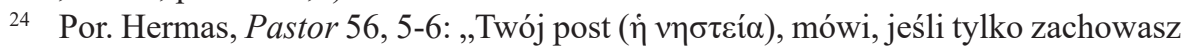
przykazania Pana, będzie bardzo piękny. Oto jak ma wyglądać ten post ( którego powinieneś przestrzegać. Przede wszystkim unikaj każdego złego słowa, każdego złego pożądania i oczyść serce swoje z wszystkich marności tego świata. Jeśli tego ze-

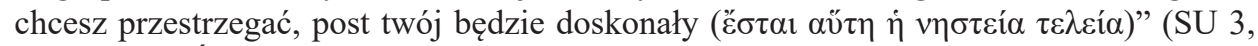
s. 258, tł. A. Świderkówna, BOK 10, s. 254).

25 Por. Hermas, Pastor 56, 7-9: „A oto jak masz postępować: kiedy spełnisz to, co

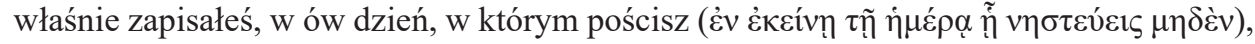

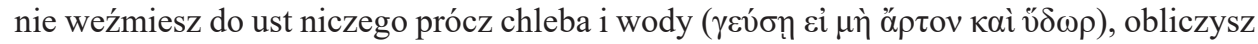
natomiast, ile byś wydał dnia tego na swoje jedzenie. I sumę tę dasz jakiejś wdowie albo sierocie albo ubogiemu. W taki właśnie sposób uniżysz się, a ten, kto dzięki temu uniżeniu się nasyci, będzie modlił się za ciebie do Pana. Jeśli więc post taki zachowasz, post zostanie ci zapisany, a służba w ten sposób pełniona będzie piękna, radosna i miła w oczach Pana (por. Koh 35,9; Iz 56,7; Mt 5,24; Flp 4,18; 1P 2,5). Tych oto zaleceń przestrzegaj wraz z twymi dziećmi i całym twoim domem, a przestrzegając będziesz szczęśliwy. I wszyscy, którzy je usłyszą i zachowają będą szczęśliwi, a o cokolwiek Pana poproszą, na pewno otrzymają" (tł. A. Świderkówna, BOK 10, s. 254).

26 Por. Liber Quartus Esdrae 5, 19-21: „Powiedziałem mu [tj. aniołowi Urielowi]: «Idź ode mnie i nie przystępuj do mnie przez siedem dni, a wtedy przyjdziesz do mnie». 
I wieku) post przez 28 dni (siedem dni postu cztery razy) skutkował otrzymaniem końcowego objawienia ${ }^{27}$. W praktyce postów prywatnych po 100 roku zarówno w judaizmie, jak i w chrześcijaństwie zwiększa się liczba dni postnych. Wydaje się, że posty wielodniowe praktykowali wizjonerzy i były one wskazane przez aniołów dialogujących z wizjonerami obu religii. Hermas wszystkim chrześcijanom zalecał natomiast posty jednodniowe (por. Pasterz 56, 7: „w ów dzień, w którym pościsz”). Co ciekawe, apokaliptyczna tradycja żydowska wydaje się zachowywać post bez jedzenia i picia (Ezdrasz je kwiaty polne i zioła, a Baruch nie je i nie pożąda żadnego jedzenia). Hermas natomiast w swej chrześcijańskiej apokalipsie ewidentnie wprowadził post o chlebie i wodzie, zalecając go nie tylko pojedynczym wizjonerom, ale także całym rodzinom.

Usłyszawszy moje słowa, odstąpił ode mnie. A ja przez siedem dni pościłem jęcząc i płacząc, jak mi polecił anioł Uriel. Po siedmiu dniach myśli mojego serca znowu stały mi się bardzo uprzykrzone" (ed. B. Violet, GCS 18, Leipzig 1910, s. 58-60, tł. S. Mędala, Apokryfy Starego Testamentu, Prymasowska Seria Biblijna 13, Warszawa 2000, s. 379); Liber Quartus Esdrae 6, 35: „Potem znowu płakałem i jeszcze pościłem przez siedem dni, aby dopełnić trzech tygodni, które zostały mi naznaczone" (GCS 18, s. 112, tł. S. Mędala, Apokryfy Starego Testamentu, s. 382); Liber Quartus Esdrae 9, 26-27: „Wyruszyłem więc, jak anioł mi polecił, na pole, które się zwie Ardat, usiadłem tam wśród kwiatów i jadłem z trwa pola, a to pożywienie było dla mnie wystarczające. Po siedmiu dniach, gdy położyłem się na sianie, moje serce znowu trwożyło się jak poprzednio" (GCS 18, s. 272, tł. S. Mędala, Apokryfy Starego Testamentu, s. 393); IV Księga Ezdrasza 10, 60-11, 1: „I spałem owej nocy, jak również następnej, jak mi polecił. Podczas drugiej nocy miałem sen" (GCS 18, s. 316, tł. S. Mędala, Apokryfy Starego Testamentu, s. 396); Liber Quartus Esdrae 12, 51-13, 1: „Ja zaś siedziałem na polu przez siedem dni, jak anioł mi polecił, i jadłem tylko z kwiatów pola; w owych dniach moim pokarmem były zioła. A po siedmiu dniach miałem w nocy sen" (GCS 18, s. 366, tł. S. Mędala, Apokryfy Starego Testamentu, s. 399-400); Liber Quartus Esdrae 13, 58-14, 1: ,[...] I przebywałem tam przez trzy dni. A trzeciego dnia, gdy siedziałem pod dębem, oto z krzaka przemówił do mnie głos [...]" (GCS 18, s. 402, tł. S. Mędala, Apokryfy Starego Testamentu, s. 402).

27 Por. Apocalipsis siriaco de Baruch 9, 2: „Rozdzieraliśmy nasze szaty, płakaliśmy, smuciliśmy się i pościliśmy siedem dni” (ed. B. Violet, GCS 32, Leipzig 1924, s. 212, tł. J. Woźniak, Apokryfy Starego Testamentu, s. 409); Apocalipsis siriaco de Baruch 12, 5: „Gdy to powiedziałem, pościłem siedem dni” (GCS 32, s. 220, tł. J. Woźniak, Apokryfy Starego Testamentu, s. 411); Apocalipsis siriaco de Baruch 21, 1: „Odszedłem stamtąd i usiadłem na brzegu Cedronu w ziemskiej jaskini i tam uświęciłem swoją duszę. Chleba nie jadłem ani nie pragnąłem, wody nie piłem ani nie pożądałem i byłem tam aż do siódmego dnia, jak mi rozkazał". Apokryfy Starego Testamentu, tł. J. Woźniak, s. 414; Apocalipsis siriaco de Baruch 47, 2: „I przyszedłem na to miejsce, gdzie rozmawiano ze mną, usiadłem tam i pościłem przez siedem dni”. Apokryfy Starego Testamentu, tł. J. Woźniak, s. 422. 


\section{Pisarze greccy i lacińscy II i III wieku o praktyce postu}

W tekstach pisarzy kościelnych okresu przełomu II i III wieku odnajdujemy również kilka istotnych wskazań dotyczących ówczesnych praktyk postnych. Pisma, które zawierają owe zalecenia, różnią się jednak od tekstów chrześcijańskich okresu poapostolskiego swą formą. Autorzy kościelni II i III wieku byli wykszattceni w greckiej tradycji literackiej, a częściowo na ich ukształtowanie miała także wpływ filozofia helleńska. Obie te tendencje są widoczne w analizowanych tekstach, co nie pozostaje bez wpływu na sam przekaz treści. Klemens Aleksandryjski, mówiąc o poście, wykorzystywał formę protreptyku i odwoływał się nie tylko do wcielonego Słowa Bożego, ale i do znanych sobie filozofów greckich. Orygenes swe przemyślenia o poście zawarł w alegorycznych komentarzach do Pisma. W tekstach łacińskich II i III wieku, jakie zawierają wzmianki o poście, dodatkowo można zaobserwować odwołanie się do roli autorytetu apostołów i normy prawa (Tradycja apostolska) oraz do prywatnych objawień (tu: montanistycznych) i do polemiki jako formy (Tertulian, O poście przeciw psychikom).

Klemens Aleksandryjski (150-ok. 212) w swoich tekstach nie podał opisu postu, ale znajdujemy tam pierwsze, jak się wydaje, opisy ascetycznej diety chrześcijańskiej. Diety te stanowią istotną część szerszego dążenia do doskonałości moralnej, które nie koncentruje się na rygoryzmie ascetycznym, ale sens nadaje mu pozostawanie w harmonii $\mathrm{z}$ Bogiem i ze światem ${ }^{28}$. Osiągnięcie takiego celu wymaga ,wstrzemięźliwości

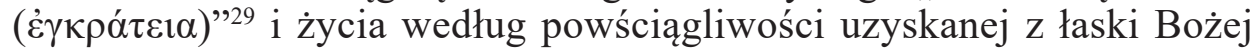

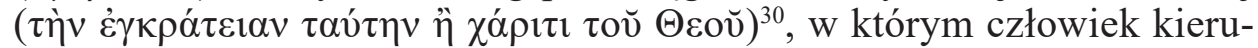

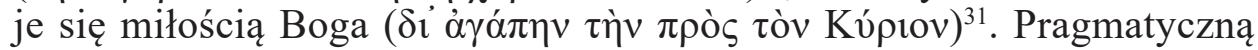

28 Por. H.-I. Marrou, Introduction Générale, w: Clément d'Alexandrie, Le Pédagogue. Livre I, SCh 70, Paris 1983, s. 57-61.

29 Clemens Alexandrinus, Stromata III 1, 4, 1: „wstrzemięźliwość jest lekceważeniem ciała w imię zgody z Bogiem" (PG 8, 1103, tł. J. Niemirska-Pliszczyńska, Klemens Aleksandryjski, Kobierce zapisków filozoficznych, PAX 33/1, Warszawa 1994, s. 231).

30 Clemens Alexandrinus, Stromata III 7, 57, 1: „Ludzka powściągliwość, której, moim zdaniem nauczają filozofowie helleńscy, głosi zasadę walki z namiętnościami i nieulegania im w postepowaniu, natomiast przez nas głoszona powściągliwość wymaga w ogóle wyrzeczenia się pożądań, to znaczy nie tego, aby panować nad namiętnościami, lecz aby nie dopuścić do ich powstania. Takiej zaś powściągliwości nie można uzyskać inaczej, jak z łaski Boga" (PG 8, 1161, tł. J. Niemirska-Pliszczyńska, PAX 33/1, s. 261). Por. T. Klibengajtis, Powściagliwość (enkráteia) w Stromatach Klemensa z Aleksandrii, „Studia Theologica Varsaviensia” 37/1 (1999) s. 53-86.

31 Clemens Alexandrinus, Stromata III 7, 59, 4: „A jeśli chodzi o nas samych, to wysoko cenimy powściągliwość, a to ze względu na naszą miłość do Pana i ze względu na samo piękno moralne, w ten sposób oddając cześć przybytkowi Ducha" (PG 8, 
w duchu chrześcijańskim była zatem wskazówka Klemensa: „Nam zaś Wychowawca przykazał jeść, by żyć. Pożywienie nie jest dla nas zajęciem, a jego przyjemność celem. Przyjmuje się je dla przetrwania zalecanego przez Wychowawcę w celu podtrzymania gatunku". Jak zauważają badacze, myśl tę Klemens zaczerpnął od rzymskiego stoika Gajusza Musoniusza Rufusa ${ }^{32}$. Klemens za Musoniuszem bardziej niż post czy specjalne diety ówczesnych atletów zalecał również proste, niewybredne posiłki służące życiu i należytej kondycji ciała ${ }^{33}$. Prostota w wyborze pokarmów i ich przyjmowaniu zwalcza obżarstwo i łakomstwo, czyli sprowadzanie życia jedynie do funkcji cielesnych, co wiedzie do zguby ${ }^{34}$. Dlatego powinno się unikać pokarmów wzbudzających żądze oraz nadmiaru pokarmów ${ }^{35}$. Bardziej niż staranie się o wystawność uczty chrześcijanin winien dbać na znak łączności i wspaniałomyślnej życzliwości wierzących o przygotowanie posiłku z miłością, lekkich i strawnych ${ }^{36}$, małych i koniecznych ${ }^{37}$. Sięgając po posiłki, należy unikać wszelkiego prostactwa i nieopanowania, jeść, zachowując czystość rąk czy brody, zachowywać miłą twarz, nie przełykać głośno, nie mówić z pełnymi ustami, nie jeść i pić jednocześnie ${ }^{38}$.

1164, tł. J. Niemirska-Pliszczyńska, PAX 33/1, s. 262-263; por. 1Kor 3,16). Więcej na ten temat, zob. P. Szczur, Aretologia agapetyczna Klemensa Aleksandryjskiego w zarysie, „Roczniki Teologiczne” 48/4 (2001) s. 5-35; B. Zgraja, Klemensa Aleksandryjskiego

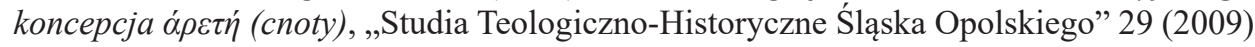
s. 211-227.

32 Zob. Clemens Alexandrinus, Paedagogus II 1, 1, ed. C. Mondésert, SCh 108, Paris 1991, s. 12, tł. M. Szarmach, Klemens Aleksandryjski, Wychowawca, Toruń 2012, s. 83. Por. C. Musonii Rufi Reliquiae, red. O. Hense, Leipzig 1990, s. 102. Klemens najprawdopodobniej zapożyczył ów cytat z diatryby Musoniusza, który z kolei przypisywał ją Sokratesowi. Inni autorzy natomiast przypisywali tę formułę Diogenesowi Leartesowi.

33 Por. Clemens Alexandrinus, Paedagogus II 1, 2, SCh 108, 12, t1. M. Szarmach, s. 83-84; por. C. Musonii Rufi Reliquiae, ed. O. Hense, s. 105.

34 Por. Clemens Alexandrinus, Paedagogus II 1, 3-4, SCh 108, s. 14-18, tł. M. Szarmach, s. 84-85.

35 Por. Clemens Alexandrinus, Paedagogus II 1, 14, SCh 108, s. 34-38, tł. M. Szarmach, s. 91-92.

36 Por. Clemens Alexandrinus, Paedagogus II 1, 6-7, SCh 108, s. 20-22, tł. M. Szarmach, s. 86-87. Zob. M. Szarmach, Stosunek pierwszych chrześcijan do uczt (Klemens Aleksandryjski, Paidagos II), „Meander” 3/4 (1994) s. 111-120.

37 Por. Clemens Alexandrinus, Paedagogus II 1, 10, SCh 108, s. 28-30, tł. M. Szarmach, s. 88.

38 Por. Clemens Alexandrinus, Paedagogus II 1, 12, SCh 108, s. 32, tł. M. Szarmach, s. $90-91$. 
Klemens zalecał nie jeść dziczyzny, gdyż według niego zaciemniała duszę, lecz kto ją spożywa, nie grzeszy, byle czynił to z umiarkowaniem $^{39}$. Wskazane w diecie (za Platonem albo za Musoniuszem Rufusem) są natomiast „,cebula, oliwki, niektóre warzywa, mleko, ser, dojrzałe owoce i gotowane potrawy, jednak bez sosów”, należy jednak zrezygnować „z pieczonego i gotowanego mięsa"40. Klemens powtarzał za tradycją platońską iż można jeść suszone owoce i miodowe wypieki ${ }^{41}$, a za przykładem Jezusa można też spożywać pieczone ryby (por. Łk 24,41-44). Klemens podawał jako własną stoicką zasadę spożywania posiłków prostych: „najbardziej odpowiednie są te pokarmy, które można spożywać zaraz, bez używania ognia, a dalej, jak powiedziałem, te proste" ${ }^{2}$. Jeśli Żydom prawo religijne zalecało prostotę $\mathrm{w}$ przyjmowaniu posiłków oraz zakazywało spożywania zwierząt, które nie są parzystokopytne i nie przeżuwają, oraz tych zwierząt morskich, które nie mają łusek (por. Kpł 11), to chrześcijanom Logos zaleca przyjmowanie pożywienia, ale w sposób ograniczony przez samokontrolę (Pedagog II 1, 16: „Naturalne apetyty należy ograniczać samokontrolą" $)^{43}$. Zalecanym napojem, jako „zdrowy i naturalny", jest woda ${ }^{44}$. Wino, jeśli pite, powinno być zmieszane Z wodą (ta w większej ilości niż wino). Normą spożywania wina jest dla Klemensa sentencja z Prz 23,33: „Nie pijcie wina aż do upicia się"45. Wino w nadmiarze prowadzi bowiem do upicia się̧6 czy do rozwiązłości

39 Por. Clemens Alexandrinus, Paedagogus II 1, 11, SCh 108, s. 30, tł. M. Szarmach, s. 89. Klemens przypisywał w tym paragrafie Pitagorasowi i jego uczniom twierdzenie o niejedzeniu mięsa i niepiciu wina, ale w ich tekstach nie znajdujemy tak kategorycznych stwierdzeń. Sam Pitagoras zabraniał jedynie spożywania niektórych mięs. Więcej na ten temat, zob. J. Carcopino, La basilique pythagoricienne de la porte majeure, Paris 1927, s. 234-236.

40 Clemens Alexandrinus, Paedagogus II 1, 15, SCh 108, s. 38, tł. M. Szarmach, s. 92. Por. Platon, Państwo II 372C; C. Musonii Rufi Reliquiae XVIII A, ed. O. Hense, s. 95. Zobacz także: K. Łapiński, Askesis w rozważaniach Muzoniusza Rufusa, „Przegląd filozoficzno-literacki” 37 (2013) s. 495-505.

41 Por. Clemens Alexandrinus, Paedagogus II 1, 15, SCh 108, s. 38, tł. M. Szarmach, s. 92. Zob. Platon, Państwo II 372C; Plutarch, Quaestiones Convivales IV 664A.

42 Clemens Alexandrinus, Paedagogus II 1, 15, SCh 108, s. 38, tł. M. Szarmach, s. 92. Zob. C. Musonii Rufi Reliquiae XVIII A, ed. O. Hense, s. 95.

43 Clemens Alexandrinus, Paedagogus II 1, 16-17, SCh 108, s. 40-44, tł. M. Szarmach, s. 92-93.

44 Clemens Alexandrinus, Paedagogus II 2, 19, SCh 108, s. 46, tł. M. Szarmach, s. 95.

45 Clemens Alexandrinus, Paedagogus II 2, 28, SCh 108, s. 62, tł. M. Szarmach, s. 99.

46 Por. Clemens Alexandrinus, Paedagogus II 2, 24, SCh 108, s. 54, tł. M. Szarmach, s. 97. 
(za Ef 5,18) $)^{47}$, dlatego ma być spożywane w sposób rozumny, kontrolowany ${ }^{48}$ i umiarkowany ${ }^{49}$.

Klemens Aleksandryjski, formułując swe opinie dotyczące chrześcijańskiej diety, starał się dokonać syntezy myśli ewangelicznej z praktyczną moralnością późnego stoicyzmu epoki imperialnej, korzystając zasadniczo z dietetycznych wskazań Musoniusza Rufusa. Realizacja cnoty w jedzeniu polegała zatem zdaniem Klemensa na kierowaniu się rozumnością, samokontrolą i umiarkowaniem, ale na wzór Logosu. Zalecenie spożywania posiłków wegetariańskich natomiast jest u Klemensa wyraźnie pochodzenia filozoficznego (zapożyczenia stoickie i platońskie).

Orygenes (185-254) wpisał post religijny w swoją koncepcję samokontroli (czyli bojaźni Bożej łączonej również z czystością, nocnymi czuwaniami, śpiewaniem hymnów i cierpliwością wobec chorych $)^{50}$, co wraz $\mathrm{z}$ praktykowaniem cnót stanowi doczesne środki w procesie naśladowania Chrystusa i nawracania do Boga ${ }^{51}$. Mówiąc o diecie, pisarz aleksandryjski podkreślał jej różnorodność i odpowiedniość. Orygenes dostrzegał wielość pokarmów stworzonych przez Boga i przystosowanych do różnorakich ludzkich potrzeb oraz odpowiednich dla różnych gatunków zwierząt. Wyróżniał zasadniczo trzy typy pokarmów: pokarm ludzi zdrowych (posilny pokarm, ludziom tym wydaje się, że mogą jeść wszystko), pokarm ludzi chorych i słabych (ze względu na słabość ludzie ci nie przyjmują posilnego pokarmu i zadowalają się jarzynami), pokarm małych dzieci (właściwe jest dla nich mleko). Zasadę diety ludzkiej stanowiła jej praktyczna odpowiedniość: „Tak więc każdy, zależnie od wieku, sił i stanu zdrowia, szuka pokarmu odpowiedniego dla siebie i pasującego do jego sił"52. Podobnie właściwą miarą odżywiania się była proporcjonalność pokarmu dostosowana do wieku człowieka, czyli inna

47 Por. Clemens Alexandrinus, Paedagogus II 2, 29, SCh 108, s. 62, tł. M. Szarmach, s. 100.

48 Por. Clemens Alexandrinus, Paedagogus II 2, 25, SCh 108, s. 56, tł. M. Szarmach, s. 98.

49 Por. Clemens Alexandrinus, Paedagogus II 2, 31, SCh 108, s. 68, tł. M. Szarmach, s. 101.

50 Por. Origenes, Expositio in Proverbia, PG 18, $196 \mathrm{~B}$.

51 Por. Origenes, In Numeros homiliae 27, 1, ed. L. Doutreleau, SCh 461, Paris, 2001, s. 270-278, tł. S. Kalinkowski, Orygenes, Homilie o Księdze Liczb, ŹMT 76, Kraków 2016, s. 293-295. Więcej na temat duchowości Orygenesa, zob. M. Szram, Chrystus jako uosobienie cnót wedtug Orygenesa, w: Droga doskonalenia chrześcijańskiego w epoce patrystycznej. Zagadnienia wybrane, red. F. Drączkowski J. Pałucki - M. Szram, Lublin 1997, s. 57-75; E. Stanula, Życie duchowe w ujęciu Orygenesa (wstęp), w: Orygenes, Homilie o Księdze Liczb, ŹMT 76, Kraków 2016, s. 9-32.

52 Origenes, In Numeros homiliae 27, 1, SCh 461, s. 270, tł. S. Kalinkowski, ŹMT 76, s. 293. 
dla dziecka, a inna dla osoby dorosłej ${ }^{53}$. Innym ograniczeniem dotyczącym jedzenia jest zakaz spożywania pokarmu z podszeptu zła, nie dla obżarstwa, bałwochwalstwa czy przyjemności, ale dla utrzymania zdrowia i zachowania sił fizycznych ${ }^{54}$.

Post religijny ma zdaniem Orygenesa znaczenie zarówno jako akt wstrzymywania się od pokarmów, ale także przenośnie jako wstrzymywanie się od wszelkiego grzechu, zła, rozwiązłości, złych słów i myśli, przewrotnej nauki czy zwodniczej filozofii, które mogą odwieść od prawdy ${ }^{55}$. Orygenes, w myśl $1 \mathrm{Tm}$ 4,3-4 $4^{56}$, odrzucał natomiast faryzejskie czy gnostyckie rozumienie postu ${ }^{57}$. Polemizując z Celsusem, Orygenes stwierdzał, w myśl Rz 14,21, Rz 14,14 i 1Kor 8,13, że objawienie Boże jedynie „radzi nie spożywać mięsa czy pić wina w trosce o bezpieczeństwo i czystość życia ludzkiego", ale Jezus uznał, że nie ma pokarmów rytualnie nieczystych, lecz wszystkie pokarmy są dozwolone do spożycia (por. Mt 15,10-20) s. $^{58}$ Odwołując się do Mt 9,159, Orygenes uznał, że dla ludzi wierzących w Chrystusa post paradoksalnie nie ma większego znaczenia, bo wierzący ciągle doświadczają obecności Chrystusa - „Niechaj więc poszczą ci, którzy utracili Oblubieńca, my zaś, mając Oblubieńca ze sobą, nie możemy pościé" ${ }^{\prime 6}$. Post jest jednak

53 Por. Origenes, In Ieremiam homiliae grecae 12, 10: „Dla każdej istoty żywej określona ilość pokarmu jest «mała»w zestawieniu z jego budową, a znowu inna ilość pokarmu jest «duża» - znowu w zestawieniu z jego organizmem. Tak samo to, co jest małe dla człowieka, może być duże dla innej istoty żywej. Na przykład to, co jest małe dla mężczyzny, jest duże dla dziecka" (tł. S. Kalinkowski, PSP 30, Warszawa 1983, s. 106).

54 Por. Origenes, Contra Celsum 8, 30, ed. M. Borret, SCh 150, Paris 1969, s. 238-240, t1. S. Kalinkowski, Orygenes, Przeciw Celsusowi, PSP 17bis, Warszawa 1986, s. 398-399.

55 Por. Origenes, In Leviticum homiliae 10, 2, ed. M. Borret, SCh 287, Paris 1981, s. 137-140, tł. S. Kalinkowski, Orygenes, Homilie o Księdze Kapłańskiej, ŹMT 69, Kraków 2013, s. 161-162.

56 1Tm 3,4: „Zabraniają oni wchodzić w związki małżeńskie, [nakazują] powstrzymywać się od pokarmów, które Bóg stworzył, aby je przyjmowali z dziękczynieniem wierzący i ci, którzy poznali prawdę. Ponieważ wszystko, co Bóg stworzył, jest dobre, i niczego, co jest spożywane z dziękczynieniem, nie należy odrzucać" (Biblia Tysiąclecia).

57 Por. Origenes, In Leviticum homiliae 10, 2, SCh 287, s. 138-140, tł. S. Kalinkowski, ŹMT 69, s. 162.

58 Por. Origenes, Contra Celsum 8, 28-29, SCh 150, s. 234-236, tł. S. Kalinkowski, PSP 17bis, s. 397-398.

59 Mt 9,15: „Jezus im rzekł: «Czy goście weselni mogą się smucić, dopóki pan młody jest z nimi? Lecz przyjdzie czas, kiedy zabiorą im pana młodego, a wtedy będą pościć»»" (Biblia Tysiąclecia).

60 Origenes, In Leviticum homiliae 10, 2, SCh 287, s. 138, tł. S. Kalinkowski, ŹMT 69, s. 162. 
dopuszczony przez Aleksandryjczyka jako jedna z praktyk ascezy chrześcijańskiej, gdyż wyrabia on postawę wstrzemięźliwości. Post pokarmowy, polegający na powstrzymywaniu się od jedzenia i picia, był zalecany chrześcijanom podczas Wielkiego Postu (brak jednak precyzacji, ile ten post miał trwać, wydaje się, że podobnie jak w Kościele Rzymu w III wieku byłyby to dwa dni przed Wielkanocą), a w tygodniu - w środy i piątki (wydaje się, że jest to pierwsze świadectwo o tym poście po Didache). Chrześcijańskie poszczenie, które prowadzi wierzącego do zajmowania się Pismami, do uzyskania wiedzy i mądrości oraz, co najważniejsze, do ukształtowania postawy powściągliwości „dla królestwa niebieskiego” (por. Mt 19,12) polega zdaniem Aleksandryjczyka na wstrzemięźliwości (czyli „powściągliwości brzucha i gardła” i odcinania się „od nadmiaru pokarmów”), a nie na zabobonnym przestrzeganiu przepisów prawnych ${ }^{61}$. Orygenes przypomina też jako „,apostolski” post postulowany przez Hermasa, którego zasadą jest: „Błogosławiony, kto pości także i po to, aby nakarmić ubogiego"62.

Orygenes, komentując Mt 9,15, wskazywał, że praktyka postu dla wierzących w Chrystusa, czyli tych, którzy są z Oblubieńcem, jest co najmniej względna. Zaznaczał też, że Jezus dopuścił do spożycia wszystkie pokarmy (Mt 15,1-20). Post religijny jest jednak dozwolony jako jeden $z$ wielu środków samokontroli. Post ten polega na wstrzemięźliwości od pokarmów (powściągliwości od jedzenia, wystrzegania się nadmiaru), to także post socjalny podejmowany w celu nakarmienia ubogiego tym, co się zaoszczędzi podczas postu. Miarą postu jest jego praktyczna odpowiedniość i proporcjonalność - dla każdego człowieka indywidualnie. Uogólniając, dla Orygenesa post to wstrzymywanie się od wszelkiego zła i grzechu.

W tekście łacińskiej Tradycji apostolskiej, będącej kompilacją kilku wcześniejszych tekstów (autorstwa najprawdopodobniej Josiposa) ${ }^{63}$, od-

61 Por. Origenes, In Leviticum homiliae 10, 2: „Nie mówię tego jednak po to, abyśmy rozluźniali cugle chrześcijańskiej wstrzemięźliwości; mamy bowiem dni Wielkiego Postu, poświęcone na poszczenie, mamy środę i piątek, kiedy uroczyście pościmy. Chrześcijanin zatem może pościć swobodnie o każdym czasie - nie przez zabobonne przestrzeganie przepisów, lecz mocą wstrzemięźliwości. Bo jak zachowana w nich może zostać doskonała czystość, jeśli nie opiera się na surowych filarach wstrzemięźliwości? Jak zajmują się Pismami, jak zabiegają o wiedze i mądrość? Czy nie przez powściągliwość brzucha i gardła? W jaki sposób ktoś «trzebi samego siebie dla królestwa niebieskiego» (por. Mt 19,12), jeśli nie odcina nadmiaru pokarmów, jeśli nie korzysta z usług wstrzemięźliwości? Chrześcijanie zatem taki mają motyw zachowywania postu” (tł. S. Kalinkowski, ŹMT 69, s. 162).

62 Origenes, In Leviticum homiliae 10, 2, SCh 287, 138, tł. S. Kalinkowski, ŹMT 69, s. 162. Por. Hermas, Pastor 56, 7-9.

63 Por. H. Pietras, Pośmiertna kariera św. Hipolita, VoxP 32-33 (1997) s. 61-75. 
najdujemy kilka wzmianek o poście. Traktują one zarówno o poście liturgicznym, jak i prywatnym. W kontekście liturgii chrzcielnej pojawia się zalecenie, aby przyjmujący chrzest pościli w piątek (,wigilię soboty”) ${ }^{64}$. Pojawia się także nakaz dwudniowego postu przed Wielkanocą (czwartek i piątek), aby chrześcijanie nic nie spożywali aż do komunii, kobiety brzemienne lub chorzy natomiast mogli ten post zachowywać w sobotę przed Paschą, przyjmując ,jedynie chleb i wodę". Podróżujący po morzu albo ci, którzy z jakiegoś powodu zapomnieli o dniu Paschy i go pominęli, powinni pościć zastępczo „za przeszły dzień po Pięćdziesiątnicy”65. Jeśli chodzi o wytyczne do prywatnego poszczenia, to zdaniem kompilatora powinni pościć praktycznie wszyscy chrześcijanie, z częstotliwością zależną od przynależności do danej grupy (wdowy i dziewice - „często”, kapłani i świeccy - „kiedy pragną”, biskup „może pościć tylko (w ten dzień), kiedy będzie pościł cały lud”) ${ }^{66}$. Kompilator jedynie zebrał wcześniejsze tradycje prawno-liturgiczne dotyczące także postu, nie podał jednak jego uzasadnienia teologicznego. Normy miały zatem obowiązywać, bo domniemywano ich apostolskie pochodzenie. Co ciekawe, jeśli przyjmie się, że kompilacja powstała $\mathrm{w}$ drugiej połowie III wieku (niektórzy sugerują nawet, że był to początek IV wieku), to dziwi brak w tym tekście wzmianek o tradycji prywatnego poszczenia w środy. Widocznie w kontekście rzymskim taki post nie był jeszcze wtedy znany.

Pierwszym traktatem chrześcijańskim w całości poświęconym zagadnieniu postu jest dzieło Tertuliana już z jego okresu montanistycznego, tj. na-

64 Traditio apostolica 19 [20]: „Gotujący się do chrztu niech poszczą (ieiunent,

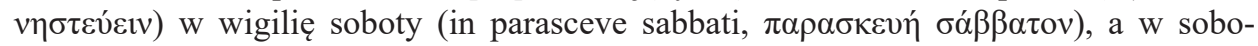
tę niech zbiorą się w jedno miejsce według wskazania biskupa". Traditio apostolica, ed. W. v Geerlings, FCh 1, Freiburg im Breisgau 1991, s. 254, tł. H. Paprocki, Tradycja Apostolska, „Studia Theologica Varsaviensia” 14/1 (1976) s. 158.

65 Traditio apostolica 33: „Niech nikt przed Paschą nie spożywa nic aż do Komunii. Kto tak nie postępuje, jego post się nie obroni. Kobieta brzemienna lub chory, który nie może pościć dwa dni, niech pości z konieczności w sobotę, zadawalając się jedynie chlebem i wodą. Jeśli ktoś natomiast będąc na morzu lub z innej konieczności nie zna dnia (Paschy), to dowiedziawszy się o tym, niech pości za przeszły dzień po Pięćdziesiątnicy. Pascha bowiem którą świętujemy nie jest symbolem. Obraz już przeszedł i dlatego post przenosi się na drugi miesiąc i kto powinien pościć, niech uczyni to rzeczywiście" (FCh 1, s. 290, tł. H. Paprocki, s. 165).

66 Traditio apostolica 23: „Wdowy i dziewice niech poszczą często (ieiunent saepe,

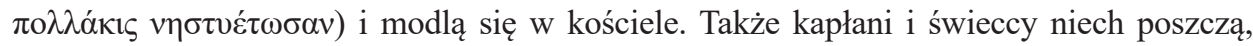

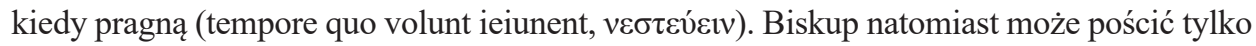
(w ten dzień), kiedy będzie pościł cały lud, bo może się zdarzyć, że ktoś zapragnie przynieść ofiarę do Kościoła, a on (biskup) nie może się od tego wymawiać. Jeżeli bowiem przełamie chleb, winien niezawodnie go spożyć" (FCh 1, s. 272, tt. H. Paprocki, s. 162). 
pisany ok. 217 roku traktat $O$ poście przeciwko psychikom (De ieiunio adversus psychicos). W swej polemice przeciwko katolikom pisarz kartagiński bronił prywatnych objawień Montana, Pryscylii i Maksymilii dotyczących postu (grzech pierwszych ludzi dokonał się poprzez spożycie jedzenia: Adam - „uległ brzuchowi niż Bogu, przytaknął raczej pokarmowi niż przykazaniu, za cenę obżarstwa sprzedał zbawienie”), jedzenie stało się niejako ,pierwotną przyczyną śmierci”, stąd głód staje się „,remedium/odtrutką” na pierwotną przyczynę grzechu w ludzkiej naturze. Dlatego Bóg chce wstrzemięźliwości ludzi od pokarmów i podoba Mu się taka ludzka wstrzemięźliwość, a jej brak jest grzechem ${ }^{67}$. Tertulian, powołując się na prywatne objawienia Parakleta, wprowadzał zatem swoją koncepcję doskonałości moralnej i nowatorską dyscyplinę dotyczącą postu. Ten programowy rygoryzm miał być $\mathrm{w}$ jego przeświadczeniu przywróceniem pełnej doskonałości ludzi duchowych. Jak zauważają polscy badacze montanizmu, np. Emil Stanula ${ }^{68}$ czy Jan Słomka ${ }^{69}$, Tertulian w swym okresie przedmontanistycznym wyprowadzał przepisy regulujące życie chrześcijańskie $\mathrm{z}$ reguły wiary, w okresie montanistycznym natomiast - z prywatnych objawień Parakleta.

Montaniści według przyjmowanych przez tę grupę prywatnych objawień - jako postów nakazanych przez Boga ${ }^{70}$ - domagali się od katolików praktyki postu ścisłego nie tylko przed chrześcijańską Paschą, ale także w każdą środę i piątek do późna, tj. do zachodu słońca, czyli dłużej niż do dziewiątej godziny dnia (obecnie godzina 15:00). Te dwa dni zaczęto nazywać „dies stationis” ('dniami stacyjnymi’). W środy i w piątki katolicy, zgodnie z tekstem Dz 3,1, pościli bowiem krócej, bo tylko do dziewiątej godziny dnia. Na dwa tygodnie przed Wielkanocą natomiast montaniści nakazywali praktykę „kserofagii” (,suchych postów”, czyli spożywanie suchych, bezmięsnych pokarmów pozbawionych sosów czy wywarów, bez soczystych owoców czy wina oraz żadnych kąpieli) ${ }^{71}$. Katolicy potę-

67 Tertullianus, De ieiunio adversus psychicos 3, 1-4, PL 2, Parisiis 1844, s. 955-957, tł. E. Stanula, PSP 65, Warszawa 2007, s. 179-180. Tertulian broni montanistycznej kserofagii w De ieiunio adversus psychicos 9, 1-9 przykładami biblijnymi abstynencji Daniela, Eliasza, Samuela i Aarona, Pawła i Tymoteusza czy podobnie nowości tzw. dni stacyjnych jako nakazanych i przedłużania postów (De ieiunio adversus psychicos 10, 1-13).

${ }_{68}$ Por. E. Stanula, Elementy montanistyczne $w$ eklezjologii Tertuliana, „Studia Theologica Varsaviensia" 9/1 (1971) s. 132.

69 Por. J. Słomka, Nowe proroctwo. Historia $i$ doktryna montanizmu, Studia Antiquitatis Christianae Series Nova 4, Katowice 2007, s. 150.

70 Por. Tertullianus, De ieiunio adversus psychicos 13, 2.

71 Por. Tertullianus, De ieiunio adversus psychicos 1, 1: „Zarzucają nam [montanistom], że przestrzegamy własnych postów, że przeciągamy stacje aż do wieczora, że za- 
piali praktyki postne montanistów jako bezprawne i nowinkarskie ${ }^{72}$, jako fałszywe i nieobowiązujące, bo pochodzące albo z pseudoproroctw, które nakazywały takie posty, albo z herezji, które są zuchwalstwem wymyślonym przez ludzi ${ }^{73}$, oraz jako nieumiarkowane w swej formie ${ }^{74}$. Kserofagia jako praktyka wstrzemięźliwości od pewnych pokarmów była również negowana przez katolików, gdyż przypominała wstrzemięźliwość rytualną podejmowaną w kultach Apisa, Izydy, Kybele czy Wielkiej Macierzy ${ }^{75}$. Ówcześni katolicy w opisie Tertuliana praktykowali post na początku III wieku tylko w dni nakazane przez Pismo i Tradycję, tj. w piątki (,„pościcie w ciągu tych dni, w których został zabrany Oblubieniec"), w posty stacyjne (,stosujecie połowiczne posty stacyjne", bo tylko do godziny 15:00) oraz posty indywidualne (, a każdy z was od czasu do czasu - według własnego widzimisię - żyje o chlebie i wodzie") $)^{76}$, ,zgodnie z własną wolą, a nie $\mathrm{z}$ nakazu" "77.

\section{Podsumowanie}

Praktyka postu religijnego $\mathrm{w}$ chrześcijaństwie $\mathrm{w}$ pierwszych trzech wiekach wydaje się być uwarunkowana kulturowo. Analizowane teksty pisarzy judeochrześcijańskich, pisane z pobudek duszpasterskich, opisują post chrześcijański w kontekście postów żydowskich. Chrześcijański post indywidualny $\mathrm{w}$ środy i piątki był najprawdopodobniej zapożyczeniem z praktyki esseńczyków z Qumran (por. Didache) w opozycji do postów indywidualnych faryzeuszy. W tym czasie chrześcijanie pościli analogicznie jak Żydzi, tj. zachowywali post przed Paschą chrześcijańską jako post wielki - od zachodu dnia poprzedniego (czwartku) do zachodu dnia następnego (piątku). W praktykach postnych I wieku postulowano odrzucenie

chowujemy surowe, bez płynów, posty (xerophagia), spożywamy pokarm bez mięsa i jakiegokolwiek mięsnego wywaru i soczystych owoców i że w jedzeniu i piciu stronimy od wina. Przestrzegamy także wstrzemięźliwość od kąpieli, odpowiednio do suchej diety" (tł. E. Stanula, PSP 65, s. 177). Por. Tertullianus, De ieiunio adversus psychicos 15, 2.

72 Por. Tertullianus, De ieiunio adversus psychicos 1, 5; 11, 1.

73 Por. Tertullianus, De ieiunio adversus psychicos 11, 2.

74 Por. Tertullianus, De ieiunio adversus psychicos 11, 3; T. Kołosowski, Chrześcijanin wobec rzeczywistości ziemskiej. Rygorystyczne stanowisko Tertuliana (artykut wstęny), w: Tertulian, Wybór pism III, PSP 65, Warszawa 2007, s. 26.

75 Por. Tertullianus, De ieiunio adversus psychicos 2, 4; 16, 7.

76 Tertullianus, De ieiunio adversus psychicos 13, 2.

77 Tertullianus, De ieiunio adversus psychicos 13, 2. 
rytualizmu i moralnego legalizmu (por. List Pseudo-Barnaby). Żydowska i chrześcijańska tradycja postna I wieku wydają się zbieżne, jeśli chodzi o zwiększanie liczby dni postnych, co było motywowane w obu tradycjach religijnych apokaliptycznymi objawieniami. Można też odnotować charakterystyczną rozbieżność w tradycjach postnych Żydów i chrześcijan I wieku w zachowywaniu postów prywatnych: faryzeusze mogli zachowywać post całodzienny w poniedziałki i czwartki, bez jedzenia i picia od wschodu do zachodu słońca danego dnia, chrześcijanie natomiast mogli praktykować post dzienny w środy i w piątki o chlebie i wodzie, od wschodu słońca do godziny 15:00.

W pedagogicznych tekstach greckojęzycznych chrześcijan aleksandryjskich przełomu II i III wieku odnajdujemy natomiast syntezę praktyki postów opartej na tradycji chrześcijańskiej ze wskazówkami ascetycznymi i dietetycznymi filozofii stoickiej i platońskiej. Wzorem cnót, tu także cnotliwego poszczenia, był Chrystus, wzorce dietetyczne natomiast zostały zapożyczone od stoików i Platona. Zalecenia Klemensa do skromnego i powściągliwego zachowania przy stole, przy spożywaniu skromnych i prostych posiłków czy dań wegetariańskich, są ewidentnie stoickie. Nakazywanie chrześcijanom przyjmowania pożywienia w sposób ograniczony przez samokontrolę zaś stanowiło już u Klemensa czy Orygenesa (wstrzemięźliwość) ideową syntezę myśli ewangelicznej z moralnością praktyczną późnego stoicyzmu rzymskiego. Co ciekawe, autorzy ci wskazywali raczej na wstrzemięźliwość jako postawę i na dietę jako wybór niż na post religijny jako taki. Co więcej, Orygenes sugerował, że chrześcijanie, doświadczając stałej obecności Oblubieńca, nie muszą pościć. Post jako swoiste remedium na grzech znajdujemy w antykatolickiej polemice Tertuliana-montanisty. W montanistycznych praktykach dwutygodniowej kserofagii znajdujemy być może zaczątki dłuższego poszczenia przed chrześcijańską Paschą. Ówczesny Kościół do III wieku włącznie jako ,wielki” zachowywał post trwający przez dwa dni bezpośrednio przed Wielkanocą (por. Orygenes czy tzw. Tradycja apostolska). Długie, dwutygodniowe suche poszczenie montanistów Kościół III wieku definiował natomiast jako bezprawne, nowinkarskie, fałszywe, nieobowiązujące, pochodzące bądź z fałszywych proroctw, bądź z herezji. Do III wieku włącznie oficjalny post był w Kościele postulowany stosunkowo rzadko (przed chrztem, oraz dwudniowy post przed Paschą). Posty indywidualne były praktykowane w środy i w piątki. Wydaje się, że dłuższe poszczenie było uznawane za przejaw fałszywych objawień bądź herezji. 


\title{
Fasting Practices in Selected Relations of Greek and Latin Writers of the First and Third century
}

\author{
(summary)
}

The practice of religious fasting in Christianity in the first three centuries seems to have been culturally conditioned. The Christian individual fasting on Wednesdays and Fridays was most likely a borrowing from the practice of the Essenes of Qumran (see Didache), in opposition to the fasting of individual Pharisees. At that time Christians fasted similarly to Jews, i.e. they kept fasting before the Christian Passover - from the sunrise of the previous day (Thursday) to the sunset of the next day (Friday). Jewish and Christian post-first-century tradition seem to coincide in increasing the number of fast-moving days, motivated in both religious traditions by apocalyptic revelations. As for the divergence in the traditions of private and Jewish ages of the first century and Jews, the Pharisaic Jews could keep all days of fast on Mondays and Thursdays without food and drink from sunrise to sunset of those days. On the other hand, Christians could practice fasting on Wednesdays and on Fridays on bread and water, from sunrise to three o'clock. For the Alexandrian Christians of the turn of the second and third century, we find a synthesis of the practice of fast Christian tradition with the ascetic and dietary philosophies of Stoic and Platonic philosophy. True to the virtues, here also virtuous fasting was Christ, while dietary patterns were borrowed from Stoics and Plato. The Alexandrian writers pointed more to temperance as an attitude and diet as a choice than a religious fasting as such. Origen, moreover, suggested that Christians do not have to fast with the Bridegroom. On the other hand, we find fast as a kind of remedy for sin in the anti-Catholic polemics of Tertullian-Montanist. In the Montanistic practices of the two-week xerophagy, we may find the beginnings of a longer, two-week fast before the Christian Passover. The Catholic Church up to the third century, named as the Great Fast, kept the post lasting for two days directly before Easter (see Origen or Apostolic Tradition). Up to the third century inclusive, the official fasting was postulated relatively rarely in the Church (before baptism and two days before Passover). Individual fasting was practiced on Wednesdays and Fridays. It seems that longer fasting was recognized in the Church until the third century as a manifestation of false revelations or heresies.

Keywords: fasting practices; early Christianity; first-third centuries AD

\section{Praktyki postne w wybranych relacjach pisarzy kościelnych greckich i lacińskich I-III wieku}

(streszczenie)

Praktyka postu religijnego w chrześcijaństwie w pierwszych trzech wiekach wydaje się być uwarunkowana kulturowo. Chrześcijański post w środy i piątki był najprawdopodobniej zapożyczeniem z praktyki Esseńczyków z Qumran (patrz Didache) w przeciwieństwie do indywidualnego postu faryzeuszy. W tym czasie chrześcijanie pościli podobnie jak Żydzi, tzn. przed chrześcijańską Paschą od wschodu słońca poprzedniego dnia (czwartek) do zachodu słońca następnego dnia (piątek). Wydaje się, że tradycja żydowska i chrześcijańska 
w pierwszym wieku zbiegają się w praktyce zwiększania liczby dni postu, co motywowano w obu tradycjach apokaliptycznymi objawieniami. Jeśli chodzi o rozbieżności w tradycjach postnych, to faryzejscy Żydzi mogli przez cały dzień pościć w poniedziałki i czwartki bez jedzenia i picia od wschodu do zachodu słońca w tych dniach. Z drugiej strony chrześcijanie mogli praktykować post w środy i piątki na chlebie i wodzie, od wschodu do trzeciej. W tekstach chrześcijan aleksandryjskich z przełomu drugiego i trzeciego wieku znajdujemy syntezę praktyki chrześcijańskiej ze zwyczajami ascetycznymi i dietetycznymi filozofii stoickiej i platońskiej. Aleksandryjscy pisarze wskazywali bardziej na umiarkowanie jako cnotę i dietę jako wybór niż na post religijny jako taki. W montanistycznych praktykach dwutygodniowej kserofagii natomiast możemy odnaleźć początek dłuższego, dwutygodniowego postu przed chrześcijańską Paschą. Kościół katolicki aż do trzeciego wieku nazywał „wielkim postem” zwyczaj poszczenia dwa dni bezpośrednio przed Wielkanocą. Do trzeciego wieku włącznie w Kościele formalny post był postulowany stosunkowo rzadko (przed chrztem i dwa dni przed Paschą). Indywidualny post był praktykowany w środy i piątki. Wydaje się też, że dłuższy post był uznawany w Kościele aż do trzeciego wieku jako przejaw fałszywych objawień lub herezji.

Słowa kluczowe: praktyki postne; wczesne chrześcijaństwo; I-III wiek

\section{Bibliografia}

\section{Źródła}

Apocalipsis siriaco de Baruch, ed. B. Violet, GCS 32, Leipzig 1924, s. 203-336, tł. J. Woźniak, Apokalipsa Barucha syryjska w: Apokryfy Starego Testamentu, Prymasowska Seria Biblijna 13, Warszawa 2000, s. 405-442.

Clemens Alexandrinus, Paedagogus, SCh 70; 108; 158, Paris 1983, tł. M. Szarmach, Klemens Aleksandryjski, Wychowawca, Toruń 2012.

Clemens Alexandrinus, Stromata (libri I-IV), PG 8, Athens 2000, s. 685-1382, tł. J. Niemirska-Pliszczyńska, Klemens Aleksandryjski, Kobierce zapisków filozoficznych (księgi I-IV), PAX 33/1, Warszawa 1994.

Didache, ed. G. Schöllgen, FCh 1, Freiburg im Breisgau 1991, s. 98-139, tł. A. Świderkówna, Didache, BOK 10, Kraków 1998, s. 33-44.

Epistula Barnabae, ed. K. Wengst, SU 2, Darmstadt 1998, s. 138-202, tł. A. Świderkówna, List Barnaby, BOK 10, Kraków 1998, s. 179-204.

Hermas, Pastor, ed. M. Leutzsch, SU 3, Darmstadt 1998, s. 146-497, tł. A. Świderkówna, Hermas, Pasterz, BOK 10, Kraków 1998, s. 205-299.

La Didaché: instructions des Apôtres, ed. J.-P. Audet, Paris 1958.

Le synaxaire arménien de Ter Israel, ed. G. Bayan - M. De Saxe, Patrologia Orientalis 18, Paris 1910.

Liber Quartus Esdrae, ed. B. Violet, GCS 18, Leipzig 1910, tł. S. Mędala, IV Księga Ezdrasza, w: Apokryfy Starego Testamentu, Prymasowska Seria Biblijna 13, Warszawa 2000, s. 372-406. 
Origenes, Contra Celsum, ed. M. Borret, SCh 150, Paris 1969, tł. S. Kalinkowski, Orygenes, Przeciw Celsusowi, PSP 17bis, Warszawa 1986.

Origenes, In Leviticum homiliae, ed. M. Borret, SCh 287, Paris 1981, tł. S. Kalinkowski, Orygenes, Homilie o Księdze Kapłańskiej, ŹMT 69, Kraków 2013.

Origenes, In Numeros homiliae, ed. L. Doutreleau, SCh 461, Paris, 2001, t1. S. Kalinkowski, Orygenes, Homilie o Księdze Liczb, ŹMT 76, Kraków 2016.

Origenes, In Ieremiam homiliae grecae, ed. J.-P. Migne, PG 13, 255-514, tł. S. Kalinkowski, Orygenes, Homilie o Księdze Jeremiasza, PSP 30, Warszawa 1983, s. 23-211.

Tertullianus, De ieiunio adversus psychicos, PL 2, Parisiis 1844, s. 953-978, tł. E. Stanula, Tertulian, O poście przeciwko psychikom, PSP 65, Warszawa 2007, s. 177-196.

Traditio apostolica, ed. W. Geerlings, FCh 1, Freiburg im Breisgau 1991, s. 143-313, t1. H. Paprocki, Tradycja Apostolska, „Studia Theologica Varsaviensia” 14/1 (1976) s. 145-169.

\section{Opracowania}

Arbesmann R., Fasten, w: Reallexicon für Antike und Christentum, t. 7, red. Th. Klauser, Stuttgart 1969, s. 447-493.

Bendowska M. - Borzmińska Z., Posty, w: Słownik judaistyczny. Dzieje. Kultura. Religia. Ludzie, t. 2, red. Z. Borzmińska - R. Żebrowski, Warszawa 2003, s. 344-345.

Classification of Fasts, w: Encyclopaedia Judaica, t. 6, red. C. Roth, Jerusalem 1973, s. 1195-1196.

Daniélou J., Teologia judeochrześcijańska. Historia doktryn chrześcijańskich przed Soborem Nicejskim, tt. S. Basista, Kraków 2002.

Ferguson E., Baptism in the Early Church. History, Theology, and Liturgy in the First Five Centuries, Grand Rapids 2009.

Herr M.D., Fasting and Fast Days, w: Encyclopaedia Judaica, t. 6, red. C. Roth, Jerusalem 1973, s. 1189-1195.

Jankowski S., Praktyka pokutna w Starym Testamencie, „Seminare” 24 (2007) s. 21-37.

Jaubert A., La date de la dernière Cène, „Revue de l'histoire des religions” 146/2 (1954) s. $140-173$.

Jaubert A., Le mercredi où Jésus fut livre, „New Testament Studies” 14 (1967) s. 145-164.

Kameraz-Kos N., Święta i obyczaje żydowskie, Warszawa 2002.

Klibengajtis T., Powściagliwość (enkráteia) w Stromatach Klemensa z Aleksandrii, „Studia Theologica Varsaviensia" 37/1 (1999) s. 53-86.

Kołosowski T., Chrześcijanin wobec rzeczywistości ziemskiej. Rygorystyczne stanowisko Tertuliana (artykut wstepny), w: Tertulian, Wybór pism III, PSP 65, Warszawa 2007, s. 7-30.

Marrou H.-I., Introduction Générale, w: Clément d'Alexandrie, Le Pédagogue. Livre I, SCh 70, Paris 1983, s. 7-97.

Musurillo H., The Problem of Ascetical Fasting in the Greek Patristic Writers, „Traditio” 12 (1956) s. 1-64. 
Pietras H., Pośmiertna kariera św. Hipolita, VoxP 32-33 (1997) s. 61-75.

Pilarczyk K., Literatura żydowska od epoki biblijnej do haskali. Wprowadzenie religioznawcze, literackie i historyczne, Kraków 2006.

Puech E., Manuskrypty znad Morza Martwego a Nowy Testament. Nowy Mojżesz, czyli o kilku praktykach Prawa, w: Qumran. Pomiędzy Starym a Nowym Testamentem, red. H. Drawnel - A. Piwowar, Analecta Biblica Lublinensia 2, Lublin 2009, s. 205-225.

Rakocy W., Faryzeusze. Historia - Ewangelie, Lublin 2002.

Scarnera A., Il digiugno cristiano dalle origini al IV secolo. Contributo per una rivalutazione teologica, Roma 1990.

Słomka J., Nowe proroctwo. Historia i doktryna montanizmu, Studia Antiquitatis Christianae Series Nova 4, Katowice 2007.

Stanula E., Elementy montanistyczne w eklezjologii Tertuliana, „Studia Theologica Varsaviensia" 9/1 (1971) s. 105-145.

Stanula E., Życie duchowe w ujęciu Orygenesa (wstęp), w: Orygenes, Homilie o Księdze Liczb, ŹMT 76, Kraków2016, s. 9-32.

Szarmach M., Stosunek pierwszych chrześcijan do uczt (Klemens Aleksandryjski, Paidagos II), „Meander” 3/4 (1994) s. 111-120.

Szczur P., Aretologia agapetyczna Klemensa Aleksandryjskiego w zarysie, „Roczniki Teologiczne" 48/4 (2001) s. 5-35.

Szram M., Chrystus jako uosobienie cnót wedtug Orygenesa, w: Droga doskonalenia chrześcijańskiego w epoce patrystycznej. Zagadnienia wybrane, red. F. Drączkowski - J. Pałucki - M. Szram, Lublin 1997, s. 57-75.

Zbroja B., Post w Biblii, „Polonia Sacra” 8/52 (2001) s. 441-448.

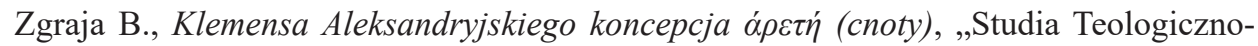
-Historyczne Śląska Opolskiego" 29 (2009) s. 211-227. 